\title{
NREL Supports Development of New National Code for Hydrogen Technologies
}

National Renewable Energy Laboratory (NREL) Team: Safety Codes and Standards Team, Hydrogen Technologies and Systems Center

Accomplishment: On December 14, 2010, the National Fire Protection Association (NFPA) issued a new national code for hydrogen technologies-NFPA 2 Hydrogen Technologies Code-which covers critical applications and operations such as hydrogen dispensing, production, and storage. The new code consolidates existing hydrogenrelated NFPA codes and standards requirements into a single document and also introduces new requirements. This consolidation makes it easier for users to prepare code-compliant permit applications and to review/approve these applications.

Context: The implementation of hydrogen technologies requires a variety of codes and standards to protect public safety. Having comprehensive codes and standards allows for permitting the full range of hydrogen technologies. NFPA 2 features hydrogen-related excerpts from the following NFPA codes and standards documents along with references to additional applicable standards:

- NFPA 55 Compressed Gas and Cryogenic Fluids Code

- NFPA 52 Vehicular Gaseous Fuel Systems Code

- NFPA 853 Standard for the Installation of Stationary Fuel Cell Power Systems

- NFPA 30A Code for Motor Fuel Dispensing Facilities and Repair Garages

- NFPA 70 National Electrical Code ${ }^{\circledR}$

- NFPA 85 Boiler and Combustion Systems Code

- NFPA 1 Uniform Fire Code ${ }^{\circledR}$

- NFPA 5000 Building Construction and Safety Code ${ }^{\circledR}$

- NFPA 88A Standard for Parking Structures

- NFPA 502 Standard for Road Tunnels, Bridges, and other Limited Access Highways.

On behalf of the U.S. Department of Energy (DOE) Fuel Cell Technologies Program, NREL supported the development of NFPA 2 in the following ways:

- NREL funded the committee work of the Hydrogen Technology Technical Committee chair, Marty Gresho of FP2 Fire, Inc.

- NREL hosted three NFPA Hydrogen Technology Technical Committee meetings, including the project kickoff meeting in November 2006.

- Robert Burgess of NREL served as a principal member of the NFPA Hydrogen Technology Technical Committee.

- NREL funded the work of Fluer, Inc., a consulting firm with expertise in code development, to make the draft code text consistent with building and fire code terminology and structure.

Applicable DOE Target: This work supports the reduction of variations in code requirements among jurisdictions, as stipulated in the Multi-Year Research, Development, and Demonstration Plan for the DOE Fuel Cell Technologies Program.

Significance of Accomplishment: The new NFPA 2 Hydrogen Technologies Code gives project developers and code enforcers a central document for navigating the spectrum of hydrogen codes and standards. This document increases the national consistency of hydrogen safety requirements by reducing variations among individual jurisdictions. It also helps project developers and code officials become more familiar with hydrogen safety requirements by giving them a single central reference document-instead of a vast collection of codes and standards documents-to comply with and enforce. 